\title{
Strawberry (cv. Romina) Methanolic Extract and Anthocyanin-Enriched Fraction Improve Lipid Profile and Antioxidant Status in HepG2 Cells
}

\author{
Tamara Y. Forbes-Hernández ${ }^{1,2}$, Massimiliano Gasparrini ${ }^{1}$, Sadia Afrin ${ }^{1}$, Danila Cianciosi ${ }^{1}$, \\ Ana M. González-Paramás ${ }^{3}$, Celestino Santos-Buelga ${ }^{3}$, Bruno Mezzetti ${ }^{4}$, José L. Quiles ${ }^{5}$, \\ Maurizio Battino ${ }^{1,6}$, Francesca Giampieri ${ }^{1, *}$ and Stefano Bompadre ${ }^{7, *}$ \\ 1 Dipartimento di Scienze Cliniche Specialistiche ed Odontostomatologiche (DISCO)-Sez. Biochimica, \\ Facoltà di Medicina, Università Politecnica delle Marche, 60131 Ancona, Italy; \\ tamara.forbe@gmail.com (T.Y.F.-H.); gaspamassi@libero.it (M.G.); dolla.bihs@gmail.com (S.A.); \\ danila.cianciosi@gmail.com (D.C.); m.a.battino@univpm.it (M.B.) \\ 2 Área de Nutrición y Salud, Universidad Internacional Iberoamericana (UNINI), \\ Campeche C.P. 24040, Mexico \\ 3 Grupo de Investigación en Polifenoles (GIP-USAL), Faculty of Pharmacy, Campus Miguel de Unamuno, \\ Salamanca University, Salamanca E-37007, Spain; paramas@usal.es (A.M.G.-P.); csb@usal.es (C.S.-B.) \\ 4 Dipartimento di Scienze Agrarie, Alimentari e Ambientali, Università Politecnica delle Marche, \\ 60131 Ancona, Italy; b.mezzetti@univpm.it \\ 5 Department of Physiology, Institute of Nutrition and Food Technology "José Mataix", \\ Biomedical Research Centre, University of Granada, Granada C.P. 18000, Spain; jlquiles@ugr.es \\ 6 Centre for Nutrition \& Health, Universidad Europea del Atlantico (UEA), Santander 39011, Spain \\ 7 Dipartimento di Scienze Biomediche e Sanità Pubblica, Università Politecnica delle Marche, \\ 60131 Ancona, Italy \\ * Correspondence: f.giampieri@univpm.it (F.G.); s.bompadre@univpm.it (S.B.); \\ Tel.: +39-071-220-4136 (F.G. \& S.B.)
}

Academic Editor: Chang Won Choi

Received: 21 December 2016; Accepted: 23 May 2017; Published: 28 May 2017

\begin{abstract}
Dyslipidemia and oxidation of low density lipoproteins (LDL) are recognized as critical factors in the development of atherosclerosis. Healthy dietary patterns, with abundant fruit and vegetable consumption, may prevent the onset of these risk factors due to the presence of phytochemical compounds. Strawberries are known for their high content of polyphenols; among them, flavonoids are the major constituents, and it is presumed that they are responsible for the biological activity of the fruit. Nevertheless, there are only a few studies that actually evaluate the effects of different fractions isolated from strawberries. In order to assess the effects of two different strawberry extracts (whole methanolic extract/anthocyanin-enriched fraction) on the lipid profile and antioxidant status in human hepatocellular carcinoma (HepG2) cells, the triglycerides and LDL-cholesterol content, lipid peroxidation, intracellular reactive oxygen species (ROS) content and antioxidant enzymes' activity on cell lysates were determined. Results demonstrated that both strawberry extracts not only improved the lipid metabolism by decreasing triglycerides and LDL-cholesterol contents, but also improved the redox state of HepG2 cells by modulating thiobarbituric acid-reactive substances production, antioxidant enzyme activity and ROS generation. The observed effects were more pronounced for the anthocyanin-enriched fraction.
\end{abstract}

Keywords: strawberry; anthocyanins; hypocholesterolemic; intracellular reactive oxygen species diminution; antioxidant 


\section{Introduction}

Fruit and vegetable consumption has been recognized as an important dietary factor that could reduce the development of many chronic diseases [1,2], including metabolic syndrome [3-5], obesity [6], diabetes [7] and cardiovascular incidents, such as hypertension [8,9], coronary heart disease, stroke [10] and myocardial infarction [8], which are currently the leading causes of death in the world [11,12].

Although the mechanisms underlying the positive effects of fruits and vegetables on cardiovascular risks' reduction are not completely clear $[8,10]$, some of their constituents such as fiber, potassium, magnesium, folate and mainly polyphenols, especially flavonoids, appear to be responsible for them [9]. The principal mechanisms proposed for dietary flavonoids regarding the protection against cardiovascular diseases (CVDs) include improvement of the endothelial function through the reduction of low density lipoproteins' (LDL) oxidation [13], the inhibition of endothelial NADPH oxidase and modulation of nitric oxide synthase activity/expression [14], the diminution of inflammatory biomarkers [15] and the enhancement of lipid profile and the redox status [13].

Rangel-Huerta et al. [15] summarized how certain foods or individual polyphenols isolated from these may interfere with the mentioned mechanisms. For example, grape ethanolic extract, resveratrol, curcumin or isoflavones decrease total cholesterol and triglyceride content and decrease oxidized LDL; while red wine, green/black tea and epillocatechin gallate-supplemented olive oil decrease inflammatory biomarkers such as necrosis factor $\alpha$, plasminogen activator inhibitor 1 and interleukin (IL)-6/IL-10.

In the particular case of LDL oxidation and altered lipid profile, these are considered critical factors in the development of atherosclerosis, since primary events of atherogenesis begin with the uptake of oxidized LDL by endothelial cells or macrophages, which leads to the accumulation of foam cells within the atherosclerotic plaques and the formation of fatty streaks. These events cause cytotoxicity and vascular dysfunction [16]. When endothelial dysfunction occurs, it induces inflammation, oxidative stress, abnormal growth, immune dysfunction, vasoconstriction, increased permeability, thrombosis and ultimately atherosclerosis [17].

Scientific evidence indicates that dietary antioxidants reduce the clinical manifestations of CVDs by reducing LDL oxidation and subsequent cellular response to oxidized LDL [18]. In that sense, strawberries present a relevant antioxidant capacity, higher (from 2- to 11-fold) than apples, peaches, pears, grapes, tomatoes, oranges or kiwifruit [19]. They are one of the richest dietary sources of phytochemicals [20,21], mainly represented by flavonoids (mainly anthocyanins, with flavonols and flavanols providing a minor contribution), followed by hydrolysable tannins (ellagitannins and gallotannins) and phenolic acids (hydroxybenzoic acids and hydroxycinnamic acids). These polyphenols are known for their antioxidant and anti-atherosclerotic properties [22]; however, it is not well understood which specific groups are responsible for the mentioned effects. Some authors suggest that the combination of antioxidant micronutrients and polyphenol compounds may play a synergistic and cumulative role in health promotion [23].

In the particular case of the Romina strawberry variety (AN99.78.51), which is a new cultivar released in 2011 as a result of the breeding program of Marche Polytechnic University (UNIVPM, Ancona, Italy), there is a growing interest due to its valuable agronomic characteristics associated with a high adaptability to non-fumigated soil and to open field cultivation in climatic conditions from the mid-Adriatic to the center-north of Europe, as well as to its resistance to the major strawberry diseases. It is also of interest for producers and consumers for its early ripening time and its nutritional quality.

According to Capocasa et al. [24], Romina fruit quality is recognized for its higher content of soluble solids (SS) $\left(7.7^{\circ}\right.$ Brix) combined with low total acidity $(10.1 \mathrm{mEq} \mathrm{NaOH} / 100$ g), which confer to the fruit a very high perception of sweetness, a well-appreciated characteristic for the consumer. To this important sensorial trait, Romina fruit also combines a high content of anthocyanins and an elevated antioxidant capacity. In addition, its contents of vitamin C, folic acid and flavonols are good, so it is expected that its health benefits are high. 
The main objective of the present work was to evaluate the effects of two different Romina strawberry extracts (whole methanolic extract/anthocyanin-enriched fraction) on the lipid profile and antioxidant status in HepG2 cells.

\section{Results}

\subsection{Characterization of Strawberry Extracts}

The results of the phytochemical and antioxidant characterization of strawberry extracts are shown in Table 1. The anthocyanin-enriched fraction revealed higher values of total polyphenol content (TPC) $(531.99 \pm 2.01 \mathrm{mg}$ GAeq/g dried weight (DW)), total flavonoids content (TFC) $(247.22 \pm 2.56 \mathrm{mg}$ CATeq/g DW) and total antioxidant capacity (TAC) $(4400 \pm 11.43 \mu \mathrm{mol}$ Txeq/g DW, by ferric-reducing antioxidant power (FRAP) assay; $1590 \pm 3.54 \mu \mathrm{mol}$ Txeq/g DW, by 2,2-diphenyl-1-picrylhydrazyl (DPPH) free radical method; $167.58 \pm 2.64 \mu \mathrm{mol} \mathrm{Txeq} / \mathrm{g}$ DW, by trolox equivalent antioxidant capacity (TEAC) assay compared to the whole methanolic extract. These results were partially expected taking into account that the anthocyanin-enriched extract is a purified fraction (in order to increase the anthocyanin concentration), while the whole methanolic extract may contain not only phytochemicals, but also other compounds, such as sugars, vitamins and other types of compounds [25] that contribute to the total weight, but not to the evaluated parameters, and may also interfere with the action of phytochemicals.

However, the marked difference between the extracts regarding the antioxidant capacity was really interesting, considering that the Romina strawberry variety contains good levels of vitamin $\mathrm{C}(38.5 \mathrm{mg} / 100 \mathrm{~g}$ fresh weight (FW)) [24], which, in addition to polyphenols, is one of the major contributors to this parameter and whose concentrations in the whole methanolic extract should be higher than in the anthocyanin-enriched fraction, taking into account that it is eliminated during the purification/concentration process.

Table 1. Phytochemical characterization and antioxidant capacity of the extracts.

\begin{tabular}{lcc}
\hline \multicolumn{1}{c}{ Parameters/Fractions } & Whole Methanolic Extract & Anthocyanin-Enriched Fraction \\
\hline Phytochemical Characterization & & \\
\hline Total polyphenols (mg GAeq/g DW) & $23.44 \pm 0.22^{\mathrm{b}}$ & $531.99 \pm 2.01^{\mathrm{a}}$ \\
Flavonoids (mg CATeq/g DW) & $5.21 \pm 0.29^{\mathrm{b}}$ & $247.22 \pm 2.56^{\mathrm{a}}$ \\
\hline TAC ( $\mu$ mol Txeq/g DW) & & \\
\hline FRAP & $168.25 \pm 3.95^{\mathrm{b}}$ & $4400 \pm 11.43^{\mathrm{a}}$ \\
DPPH & $30.29 \pm 0.18^{\mathrm{b}}$ & $1590 \pm 3.54^{\mathrm{a}}$ \\
TEAC & $35.51 \pm 0.06^{\mathrm{b}}$ & $167.58 \pm 2.64^{\mathrm{a}}$ \\
\hline
\end{tabular}

mg GAeq/g DW: $\mathrm{mg}$ of gallic acid equivalent/g of the dried weight (DW) of the fraction. $\mathrm{mg}$ CATeq/g DW: $\mathrm{mg}$ of catechin equivalent/g of the dried weight (DW) of the fraction. $\mu \mathrm{mol}$ Txeq/g DW: $\mu$ mol of Trolox equivalent/g of the dried weight (DW) of the fraction. FRAP: ferric-reducing antioxidant power assay. DPPH: 2,2-diphenyl-1-picrylhydrazyl free radical method. TEAC: trolox equivalent antioxidant capacity assay; TAC, total antioxidant capacity. Different superscripts letter for each column indicated significant differences $(p<0.05)$.

The anthocyanin family is definitely the major component of both fractions, representing approximately $86 \%$ to $94 \%$ of the total phenolic compound identified through the high performance liquid chromatography (HPLC) analysis (Table 2). These results are in accordance with the data reported by He et al. [26], who evaluate different methods for anthocyanin isolation from fruits and vegetables, obtaining anthocyanins with purity over $83 \%$ when the traditional C18 method of solid phase extraction (SPE) was employed.

Other phenolic compounds (ellagic acid derivatives and flavonols/dihydroflavonols) have also been identified in both fractions even though in a small quantity. 
Table 2. Identification and quantification of the main phenolic compounds present in both fractions.

\begin{tabular}{|c|c|c|c|c|c|c|}
\hline $\begin{array}{l}\text { Peak } \\
\text { Number }\end{array}$ & $\begin{array}{l}\lambda_{\max } \\
(\mathrm{nm})\end{array}$ & $\begin{array}{l}{[\mathrm{M}]^{+}} \\
(\mathrm{m} / \mathrm{z})\end{array}$ & $\begin{array}{c}\mathrm{MS}^{2} 2^{\text {nd }} \\
\text { Stage of MS } \\
\text { Spectrometry }\end{array}$ & Tentative Identification & $\begin{array}{c}\text { Whole } \\
\text { Methanolic } \\
\text { Extract }\end{array}$ & $\begin{array}{l}\text { Anthocyanin- } \\
\text { Enriched } \\
\text { Fraction }\end{array}$ \\
\hline \multicolumn{7}{|c|}{ Anthocyanins (Expressed as Pg 3-O-glc) (mg/g DW) ${ }^{1}$} \\
\hline 1 & 515 & 449 & 287 & Cyanidin 3-O-glucoside & $0.02 \pm 0.00$ & $3.98 \pm 0.08$ \\
\hline 2 & 500 & 595 & 433,271 & Pelargonidin 3,5-diglucoside & $<\mathrm{LOQ}$ & $1.55 \pm 0.03$ \\
\hline 3 & 502 & 433 & 271 & Pelargonidin 3-O-glucoside & $29.30 \pm 0.59$ & $266.76 \pm 5.34$ \\
\hline 4 & 505 & 681 & 271 & Pg 3-malonyldiglucoside & $<$ LOQ & $1.40 \pm 0.03$ \\
\hline 5 & 507 & 519 & 271 & Pg 3-malonylglucoside & $5.20 \pm 0.10$ & $59.50 \pm 1.19$ \\
\hline 6 & 505 & 475 & 271 & Pg 3-acetylglucoside & $<$ LOQ & $0.87 \pm 0.02$ \\
\hline \multicolumn{5}{|c|}{ Total } & 34.52 & 334.06 \\
\hline $\begin{array}{l}\text { Peak } \\
\text { Number }\end{array}$ & $\begin{array}{l}\lambda_{\max } \\
(\mathrm{nm})\end{array}$ & $\begin{array}{c}{[\mathrm{M}-\mathrm{H}]^{-}} \\
(\mathrm{m} / \mathrm{z})\end{array}$ & MS $^{2}$ & Tentative Identification & $\begin{array}{c}\text { Whole } \\
\text { Methanolic } \\
\text { Extract }\end{array}$ & $\begin{array}{l}\text { Anthocyanin- } \\
\text { Enriched } \\
\text { Fraction }\end{array}$ \\
\hline \multicolumn{7}{|c|}{ Ellagic Acid Derivatives (Expressed as Ellagic Acid) $(\mathrm{mg} / \mathrm{g} \mathrm{DW})^{1}$} \\
\hline 7 & 273 & 935,467 & $633,391,301$ & $\begin{array}{l}\text { Galloyl-bis- hexahydroxydipenoyl } \\
\text { HHDP-glucose isomer }\end{array}$ & $0.40 \pm 0.03$ & $8.07 \pm 0.56$ \\
\hline 8 & 273 & 935,447 & 301 & Galloyl-bis-HHDP-glucose isomer & $0.80 \pm 0.06$ & $21.17 \pm 1.48$ \\
\hline 9 & 343 & 949,477 & $779,447,301$ & $\begin{array}{l}\text { Possible galloyl-HHDP- } \\
\text { dehydrohexahydroxydiphenic acid-hexose }\end{array}$ & $0.04 \pm 0.00$ & $2.14 \pm 0.15$ \\
\hline 10 & $250 / 367$ & 447 & 301 & Ellagic acid deoxyhexoside & $<$ LOQ & $1.82 \pm 0.13$ \\
\hline 11 & $250 / 366$ & 301 & 284,256 & Ellagic acid & $0.50 \pm 0.04$ & $11.40 \pm 0.80$ \\
\hline \multicolumn{5}{|c|}{ Total } & 1.74 & 44.60 \\
\hline \multicolumn{7}{|c|}{ Flavonols/Dihydroflavonols (Expressed as, Quercetin or Kaempferol Glucoside) (mg/g DW) ${ }^{1}$} \\
\hline 12 & 352 & 477 & 301 & Quercetin glucuronide & $0.06 \pm 0.00$ & $2.98 \pm 0.15$ \\
\hline 13 & 347 & 461 & 447,285 & Kaempferol glucuronide & $0.10 \pm 0.01$ & $3.89 \pm 0.19$ \\
\hline 14 & 347 & 489 & 285 & Kaempferol acyl glucoside & $0.10 \pm 0.01$ & $2.18 \pm 0.11$ \\
\hline \multicolumn{5}{|c|}{ Total } & 0.26 & 9.05 \\
\hline
\end{tabular}

${ }^{1} \mathrm{mg} / \mathrm{g}$ DW: $\mathrm{mg}$ of representative compound/g of the dried weight (DW) of the fraction.

The main anthocyanin identified, pelargonidin 3-O-glucoside, represented $80 \%$ of the total anthocyanins, which is in correspondence with the principal anthocyanin reported for strawberries. In the fresh fruit pelargonidin-3-O-glucoside, cyanidin-3-O-glucoside and pelargonidin-3-O-rutinoside are recognized as the major compounds of this family [27-29], contributing on average to $41 \%$ of the TPC [28]. The total concentration of this group of phenolic compounds varies from 8.5 to $65.9 \mathrm{mg} / 100 \mathrm{~g}$ fresh weight (FW) [27-29] depending on strawberry variety, climactic conditions and post-harvest handling procedures, among other factors. The following two groups that have a greater contribution to the TPC in strawberry are flavonols and ellagitannins $[27,28]$.

\subsection{Effects of Strawberry Extracts on HepG2 Cell Viability}

To evaluate the possible cytotoxic effects of strawberry fractions in HepG2 cells, an MTT (3-(4,5-dimethylthiazol-2-yl)-2,5-diphenyltetrazolium bromide) assay was performed. Cells were incubated with extensive concentration ranges of both the whole methanolic extract and the anthocyanin fraction for $24 \mathrm{~h}$

After treatment with the whole methanolic extract, cell viability was not significantly affected $(p<0.05)$ at concentrations up to $100 \mu \mathrm{g} / \mathrm{mL}$, but significant cytotoxicity was revealed at higher concentrations. Likewise, the anthocyanin-enriched fraction at concentrations lower than $50 \mu \mathrm{g} / \mathrm{mL}$ did not cause significant $(p<0.05)$ cell death compared to the control (Figure 1). Hence, the concentrations of 10,50 and $100 \mu \mathrm{g} / \mathrm{mL}$ of whole methanolic extract and 5, 10 and $50 \mu \mathrm{g} / \mathrm{mL}$ of the anthocyanin fraction, corresponding to approximately 98,95 and $91 \%$ of viable cells, respectively, were used in subsequent experiments. 

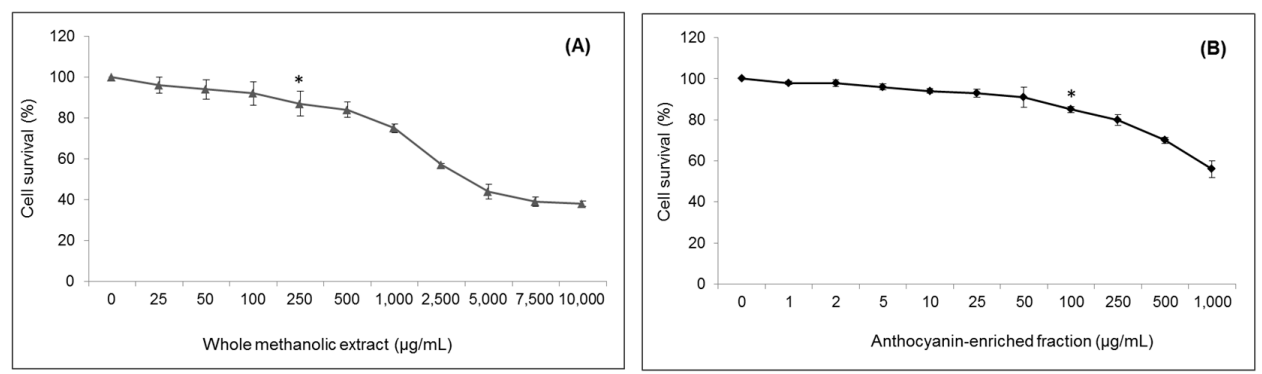

Figure 1. Viability of HepG2 cells after treatment with strawberry whole methanolic extract (A) and the anthocyanin-enriched fraction (B). Cells were treated with the indicated concentration of strawberry extracts for $24 \mathrm{~h}$. Values are expressed as the mean \pm SD of three independent experiments $(n=3)$. The asterisk indicates the concentrations from which significant differences $(p<0.05)$ were observed compared to the control.

\subsection{Effects of Strawberry Extracts on Lipid Profile and Lipid Peroxidation}

As shown in Figure 2, strawberry whole methanolic extract significantly $(p<0.05)$ decreased triglyceride levels in a dose-dependent manner up to 0.40 -fold compared to the control when applied at the highest concentration evaluated $(100 \mu \mathrm{g} / \mathrm{mL})$. In the case of the anthocyanin-enriched fraction, no significant differences $(p<0.05)$ were observed between the two lowest concentrations $(5$ and $10 \mu \mathrm{g} / \mathrm{mL})$, but in all cases, the triglyceride level diminution was significant $(p<0.05)$ compared to the untreated cells, reaching 0.46 -fold when applied at $50 \mu \mathrm{g} / \mathrm{mL}$.

LDL-cholesterol levels were also significantly $(p<0.05)$ decreased by both strawberry extracts (Figure 2). Maximum concentrations of the whole methanolic extract/anthocyanin-enriched fraction caused a diminution of this indicator up to 0.30 - and 0.19 -fold compared to the control, respectively.
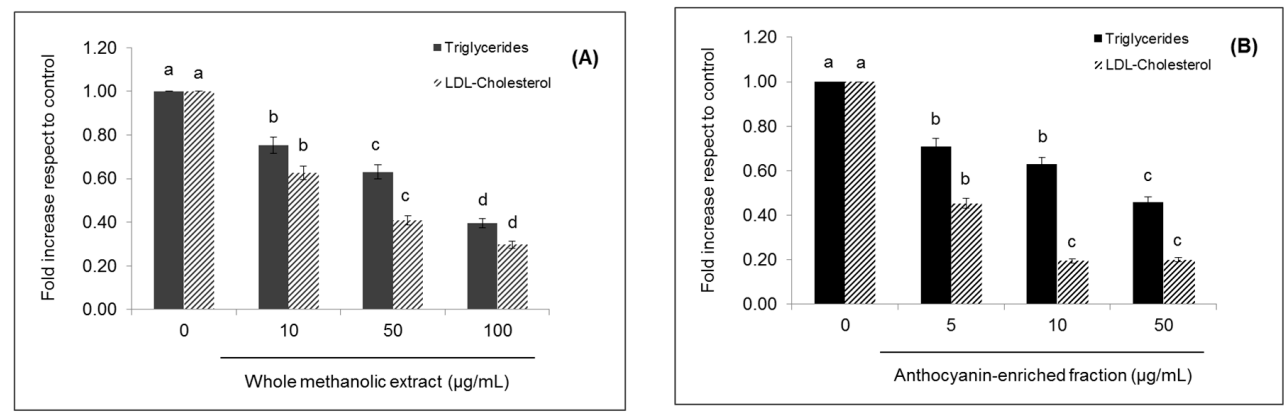

Figure 2. Effects of strawberry whole methanolic extract (A) and the anthocyanin-enriched fraction (B) on triglycerides and LDL-cholesterol content in HepG2 cells. Cells were treated with the indicated concentration of strawberry extracts for $24 \mathrm{~h}$. The concentration of $0 \mu \mathrm{g} / \mathrm{mL}$ corresponds to the control (untreated cells). Values are expressed as the mean $\pm \mathrm{SD}(n=3)$ of three independent experiments. Columns belonging to the same set of data with different superscript letters are significantly different $(p<0.05)$.

Although for both extracts, higher effects were observed at the higher concentrations used, already at the lower concentration, the decrease in the content of triglycerides and LDL-cholesterol was significant $(p<0.05)$ compared to the control.

Furthermore, strawberry extracts not only improved the lipid profile by lowering LDL-cholesterol and triglyceride levels, but also reduced lipid peroxidation, as shown in Figure 3. Certain diagnostic tests are available for the quantification of the end-products of lipid peroxidation, with the thiobarbituric acid-reactive substance (TBARs) assay as the most commonly used. The highest concentrations of both strawberry extracts significantly $(p<0.05)$ decreased the TBARs levels up to 0.18 -fold compared to untreated cells. 


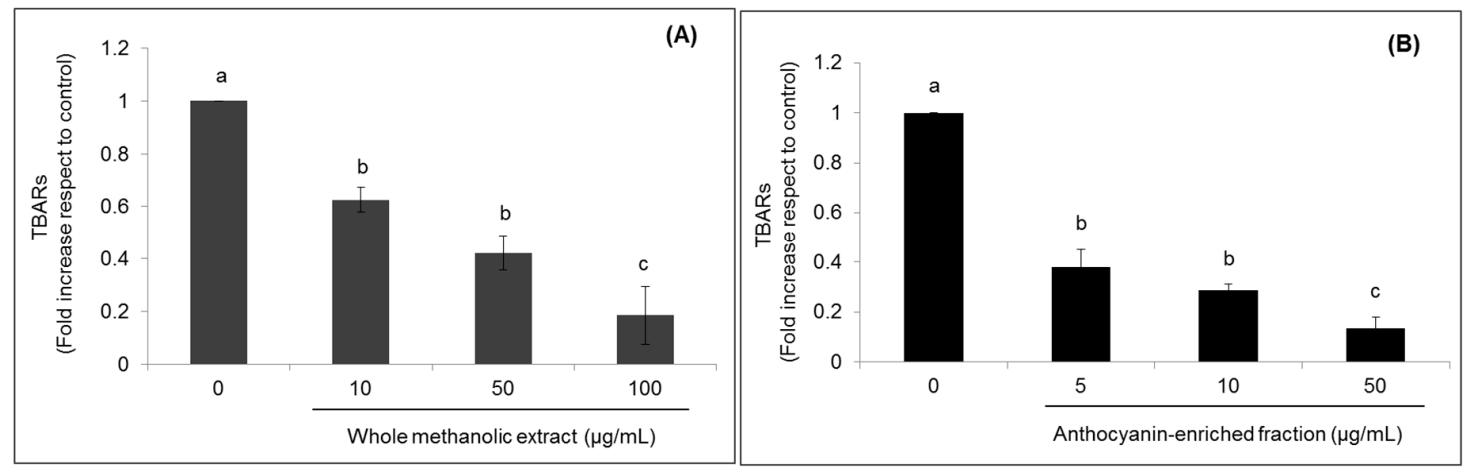

Figure 3. Effects of strawberry whole methanolic extract (A) and the anthocyanin-enriched fraction (B) on lipid peroxidation in HepG2 cells. Cells were treated with the indicated concentration of strawberry extracts for $24 \mathrm{~h}$. The concentration of $0 \mu \mathrm{g} / \mathrm{mL}$ corresponds to the control (untreated cells). Values are expressed as the mean $\pm \mathrm{SD}$ of three independent experiments $(n=3)$. Columns belonging to the same set of data with different superscript letters are significantly different $(p<0.05)$.

\subsection{Effects of Strawberry Extracts on Intracellular Production of Reactive Oxygen Species and Antioxidant Enzyme Activity}

Regarding intracellular reactive oxygen species (ROS) production, a significant diminution $(p<0.05)$ was outlined in cells supplemented with both strawberry extracts (Figure 4). After $24 \mathrm{~h}$ of treatment, whole methanolic extract caused a decrease up to 0.43 -fold compared to untreated cells independently of the concentrations in which it was applied. Meanwhile, the anthocyanin-enriched fraction caused a diminution of 0.30 - and 0.20 -fold when it was applied at 5 to 10 and $50 \mu \mathrm{g} / \mathrm{mL}$, respectively.

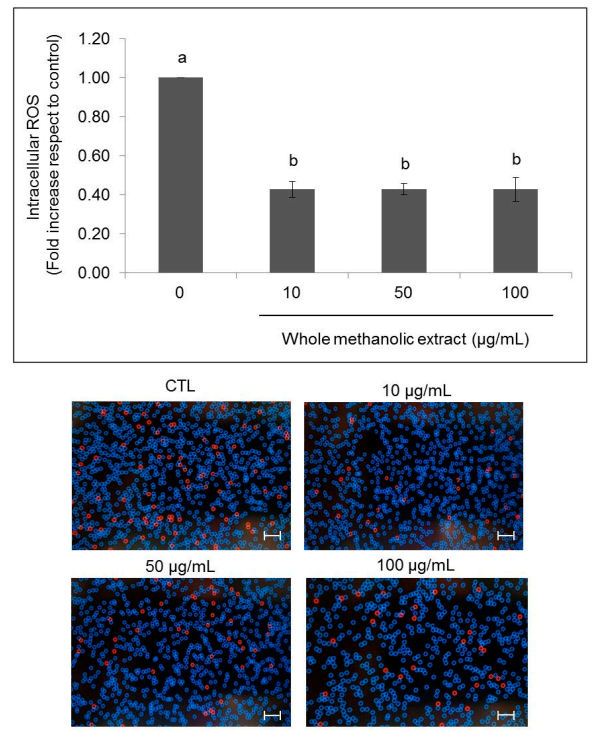

(A)

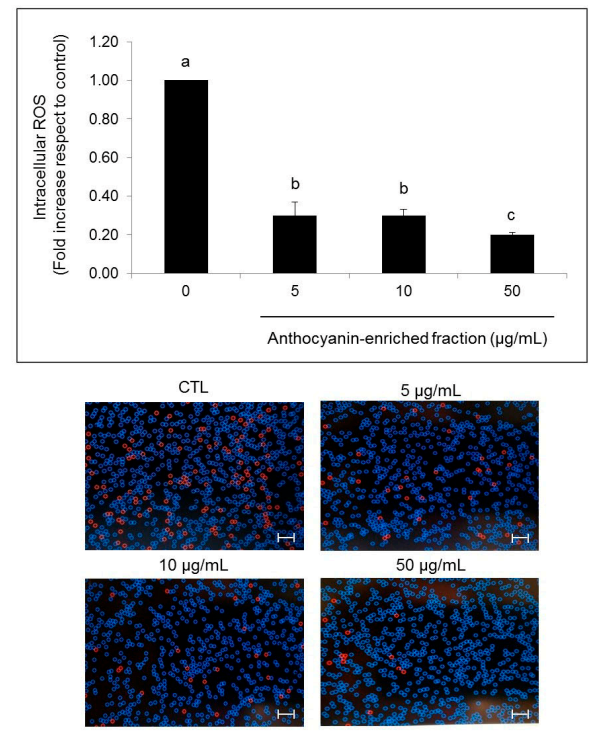

(B)

Figure 4. Effects of strawberry whole methanolic extract (A) and the anthocyanin-enriched fraction (B) on intracellular reactive oxygen species (ROS) production in HepG2 cells. Cells were treated with the indicated concentration of strawberry extracts for $24 \mathrm{~h}$. The concentration of $0 \mu \mathrm{g} / \mathrm{mL}$ corresponds to the control (untreated cells). Scale bar, $50 \mu \mathrm{m}$. Representative images of intracellular ROS quantification by the Tali ${ }^{\circledR}$ Image-Based Cytometer (Thermo Fisher Scientific, Milan, Italy) are shown following the graphs (stressed cells appear red). Values are expressed as the mean \pm SD of three independent experiments $(n=3)$. Columns belonging to the same set of data with different superscript letters are significantly different $(p<0.05)$. 
Closely related to the intracellular ROS production and lipid peroxidation is the state of the antioxidant defense systems. Hence, the activity of the antioxidant enzymes superoxide dismutase (SOD) and catalase (CAT) were also evaluated. SOD activity significantly increased $(p<0.05)$ up to 1.15-fold compared to the control, after treatment with dried methanolic extract (50 and $100 \mu \mathrm{g} / \mathrm{mL}$ ) (Figure $5 \mathrm{~A}$ ) or the anthocyanin fraction at $50 \mu \mathrm{g} / \mathrm{mL}$ (Figure 5B). The lowest concentration evaluated for both extracts (5 or $10 \mu \mathrm{g} / \mathrm{mL}$ ) did not cause significant $(p<0.05)$ effects compared to untreated cells.
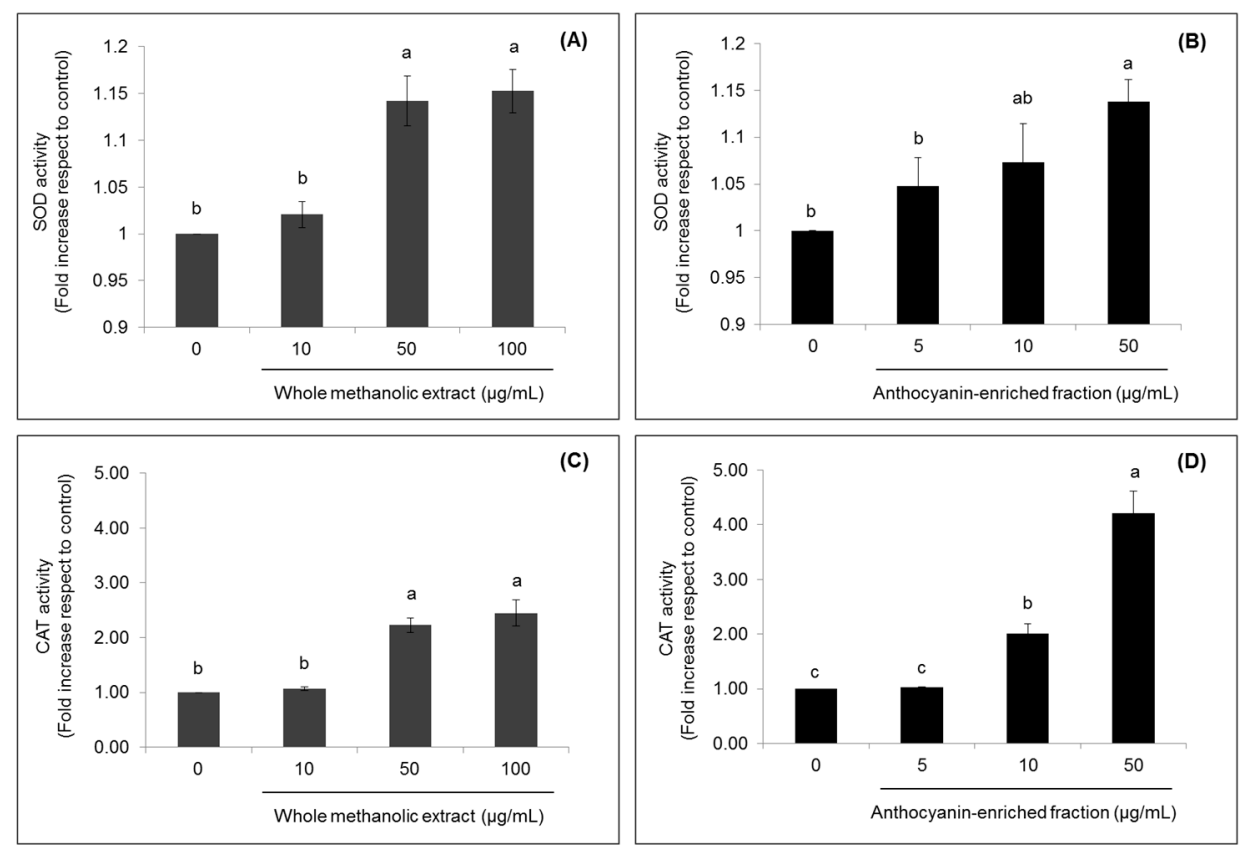

Figure 5. Effects of strawberry whole methanolic extract $(\mathrm{A}, \mathrm{C})$ and the anthocyanin-enriched fraction (B,D) on superoxide dismutase (SOD) and catalase (CAT) activities in HepG2 cells. Cells were treated with the indicated concentrations of strawberry extracts for $24 \mathrm{~h}$. The concentration of $0 \mu \mathrm{g} / \mathrm{mL}$ corresponds to the control (untreated cells). Values are expressed as the mean $\pm \mathrm{SD}$ of three independent experiments $(n=3)$. Columns belonging to the same set of data with different superscript letters are significantly different $(p<0.05)$.

Furthermore, the CAT activity significantly increased $(p<0.05)$ after treatment with strawberry extracts, even in a greater proportion compared to the effects observed for SOD. In cells treated with 50 and $100 \mu \mathrm{g} / \mathrm{mL}$ of whole methanolic extract, CAT activity was respectively 2.22- and 2.45-fold higher compared to the control, while in those cells treated with 10 and $50 \mu \mathrm{g} / \mathrm{mL}$ of the anthocyanin-enriched fraction, it increased up to 2.01- and 4.21-fold compared to untreated cells, respectively; in this case, the minimal concentrations evaluated of both extracts did not have a significant $(p<0.05)$ effect on the enzyme activity.

Comparing the effects that were caused by both strawberry extracts when applied at the same concentrations (10 and $50 \mu \mathrm{g} / \mathrm{mL}$ ), it can be noticed that the anthocyanin-enriched fraction was more effective in almost all cases (Table 3 ), excluding the effect in SOD activity where no significant differences were observed $(p<0.05)$.

Interestingly, the major difference between the two extracts was observed in the induction of the other antioxidant enzyme activity, CAT. The anthocyanin-enriched extract caused an increase in CAT activity $94 \%$ and 199\% higher than the whole methanolic extract when applied at 10 and $50 \mu \mathrm{g} / \mathrm{mL}$, respectively. 
Table 3. Comparison between strawberry fractions when applied at the same concentrations.

\begin{tabular}{|c|c|c|c|c|c|c|}
\hline \multirow[b]{2}{*}{ Parameters * } & \multicolumn{3}{|c|}{$10 \mu \mathrm{g} / \mathrm{mL}$} & \multicolumn{3}{|c|}{$50 \mu \mathrm{g} / \mathrm{mL}$} \\
\hline & $\begin{array}{c}\text { Whole } \\
\text { Methanolic } \\
\text { Extract }\end{array}$ & $\begin{array}{l}\text { Anthocyanin- } \\
\text { Enriched } \\
\text { Fraction }\end{array}$ & $\begin{array}{l}\text { Difference } \\
(\%)\end{array}$ & $\begin{array}{c}\text { Whole } \\
\text { Methanolic } \\
\text { Extract }\end{array}$ & $\begin{array}{l}\text { Anthocyanin- } \\
\text { Enriched } \\
\text { Fraction }\end{array}$ & $\begin{array}{c}\text { Difference } \\
(\%)\end{array}$ \\
\hline $\begin{array}{l}\text { Triglyceride Content } \\
\text { Low Density }\end{array}$ & $0.75 \pm 0.04^{\mathrm{a}}$ & $0.63 \pm 0.03^{b}$ & 12 & $0.63 \pm 0.03^{a}$ & $0.46 \pm 0.02^{b}$ & 17 \\
\hline $\begin{array}{c}\text { Lipoproteins- } \\
\text { Cholesterol Content }\end{array}$ & $0.63 \pm 0.03^{\mathrm{a}}$ & $0.45 \pm 0.02^{b}$ & 18 & $0.41 \pm 0.02^{\mathrm{a}}$ & $0.19 \pm 0.01^{b}$ & 22 \\
\hline $\begin{array}{l}\text { Lipid Peroxidation } \\
\text { Intracellular }\end{array}$ & $0.63 \pm 0.05^{\mathrm{a}}$ & $0.29 \pm 0.02^{b}$ & 34 & $0.42 \pm 0.07^{\mathrm{a}}$ & $0.18 \pm 0.11^{b}$ & 24 \\
\hline $\begin{array}{l}\text { Reactive Oxygen } \\
\text { Species Production }\end{array}$ & $0.43 \pm 0.04^{\mathrm{a}}$ & $0.30 \pm 0.03^{b}$ & 13 & $0.43 \pm 0.03^{a}$ & $0.20 \pm 0.01^{b}$ & 23 \\
\hline $\begin{array}{c}\text { Superoxide } \\
\text { Dismutase Activity }\end{array}$ & $1.02 \pm 0.01^{\mathrm{a}}$ & $1.07 \pm 0.04^{\mathrm{a}}$ & 0.5 & $1.14 \pm 0.03^{a}$ & $1.14 \pm 0.02^{\mathrm{a}}$ & 0 \\
\hline Catalase Activity & $1.07 \pm 0.04^{b}$ & $2.01 \pm 0.18^{a}$ & 94 & $2.22 \pm 0.14^{b}$ & $4.21 \pm 0.41^{\mathrm{a}}$ & 199 \\
\hline
\end{tabular}

* Expressed as the fold increase with respect to the control. Different superscript letters for each evaluated parameter and corresponding with the same concentration indicate significant differences $(p<0.05)$ between strawberry fractions.

\section{Discussion}

In the present work, we demonstrated that two different strawberry fractions (whole methanolic extract and the anthocyanin-enriched fraction) decreased total cholesterol and triglyceride content, lipid peroxidation, intracellular ROS production and increased antioxidant enzymes' activity, although to different extents.

For all of the evaluated parameters, the anthocyanin-enriched fraction resulted in being more effective than the whole methanolic extract, since lower concentrations were needed to obtain similar effects, or in other words, when they were applied at equal concentrations, the effects for the anthocyanin fraction were more noticeable.

Although there are only a few studies evaluating the biological effects of anthocyanins isolated from strawberries, the hypothesis that these compounds are mainly responsible for the biological activities of this fruit has been sustained by some authors. For example, Prior et al. [30] demonstrated that supplementation of drinking water with purified anthocyanins, but not whole strawberries, altered the development of obesity in mice. Likewise, Fotschki et al. [31] confirmed that the addition of anthocyanins in a strawberry polyphenolic extract enhanced the positive effects of diets with fructooligosaccharides (FOS) in the rat cecal environment.

Other results from human studies evaluating the effects of anthocyanins isolated from berries on human health demonstrated that supplementation with $320 \mathrm{mg} /$ day of purified anthocyanins from bilberries (Vaccinium myrtillus) and black currants (Ribes nigrum) for 12 weeks decreased LDL-cholesterol levels (up to 13.6\%) in dyslipidemic subjects [32], while the ingestion of $500 \mathrm{mg} /$ day of elderberry extract for the same period of time resulted in being ineffective in improving biomarkers of CVDs' risk in healthy postmenopausal women [33].

It has been suggested that anthocyanins are the major contributors to the TAC of berries [34], nevertheless, it would be interesting to further analyze if they are also mainly responsible for other biological activities reported for strawberries, how the structure could affect these properties and what are the potential synergistic interactions among the anthocyanins. It would also be interesting to evaluate the biological properties of the metabolites resulting from the digestion of these compounds, since it has been demonstrated that anthocyanin bioavailability is relatively low (relative urinary excretions, ranging from $0.004 \%$ to $0.1 \%$ of the intake) compared to other polyphenols $[29,35]$.

For example, in a study conducted by Banaszewski et al. [36], the maximal concentrations of pelargonidin-3-O-glucoside (the most abundant metabolite identified) achieved in the plasma of healthy volunteers after $148 \pm 31$ min of having consumed four beverages containing $0,10,20$ and $40 \mathrm{~g}$ of strawberry powder were $0,93.4 \pm 21.9,166.5 \pm 16.2$ and $226.7 \pm 36.7 \mathrm{nmol} / \mathrm{L}$, respectively. In addition, some authors have demonstrated that also the timing of intake may influence anthocyanin 
bioavailability and therefore their health promoting effects. In that sense, Sandhu et al. [29] have reported that plasma concentration of pelargonidin-3-O-glucoside increased $\approx 66 \%$ when a strawberry drink was consumed in a fasted state compared to the fed state.

In general, although many researchers are investigating the potential health benefits of fruit anthocyanins, in most cases, they use crude extracts without eliminating potentially bioactive impurities, which could have biological effects, creating interference in the bioassays. Access to high-purity anthocyanin extracts is essential for the validity of such research.

Removal of undesirable compounds from anthocyanin extracts can also be of great importance for the food and nutraceutical industries. Sugars, phenolic compounds, amino acids and metals accelerate the degradation of anthocyanins, and therefore, high purity is desirable for improved stability [26].

However, these results may have a different interpretation, in the sense that greater quantities of strawberries are required to obtain the same amount of the anthocyanin fraction as the crude extract (in this work, $1 \mathrm{mg}$ of whole methanolic extract was obtained from $23.31 \mathrm{mg}$ of fresh fruit while $1 \mathrm{mg}$ of the anthocyanin-enriched fraction was obtained from $211.90 \mathrm{mg}$ fresh fruit), an aspect that must be taken into consideration during the formulation of nutraceutical products using strawberry as a bioactive ingredient.

Concerning the lipid peroxidation inhibition, our overall data were in correspondence with the results obtained by Giampieri et al. [37] and Alvarez-Suarez et al. [38] who reported that strawberry polyphenols are able to suppress lipid peroxidation in vitro and in vivo, respectively.

Lipid peroxidation is a complex process that involves the formation and propagation of lipid radicals, the uptake of oxygen, a rearrangement of the double bonds in unsaturated lipids and the eventual destruction of membrane lipids, with the production of a variety of breakdown products. Its inhibition occurs through enzymatic reactions or through free radical scavenging by antioxidants. An increased concentration of end products of lipid peroxidation is the evidence most frequently quoted for the involvement of free radicals in human disease. Actually, lipid peroxidation is considered as one of the principal molecular mechanisms involved in oxidative damage to cell structures and in the toxicity process that leads to cell death [39]. In atherosclerosis and in worsening the initial tissue injury caused by ischemic or traumatic brain damage, lipid peroxidation seems to play an important pathological role. Hence, its inhibition/diminution is crucial to preventing these diseases, and for that reason, the role of antioxidants has received extensive attention.

Likewise, the diminution of intracellular ROS production by strawberry methanolic extract has also been reported by Giampieri et al. [40,41] in human dermal fibroblasts stressed with 2,2'-azobis(2-amidinopropane) dihydrochloride (AAPH) or hydrogen peroxide $\left(\mathrm{H}_{2} \mathrm{O}_{2}\right)$, respectively; but there is no information about strawberry anthocyanin fraction effects. The clinical implications of elevated ROS production can be severe and become a major cause of molecular injury leading to cell aging and to age-related degenerative diseases. In this regard, the liver is particularly susceptible to toxic and oxidative insults.

Regarding antioxidant enzyme activities, the obtained results were in agreement with the observed decrease in lipid peroxidation and intracellular ROS production since, as mentioned above, these three aspects are closely related. Changes in the activity of antioxidant enzymes can be considered as biomarkers of the antioxidant response. SOD, a free radical scavenger, is one of the major defenses against the oxidizing effect of the superoxide radical. It could protect cells from the toxicity of superoxide radicals by transforming them to $\mathrm{H}_{2} \mathrm{O}_{2}$, which is subsequently converted by CAT in water and oxygen. In HepG2 cells, the improvement of SOD and CAT activities has also been reported after treatment with some natural compounds, such as blueberry anthocyanidins [42], bioactive compounds of endophytic fungus from pigeon pea [43], cocoa polyphenolic extract [44] and resveratrol [45].

In our opinion, the observed effects of strawberry fractions may depend not only on their antioxidant capacity, but also on their ability to activate endogenous defense systems probably through the AMP-activated protein kinase (AMPK) pathway. AMPK could be involved in the antioxidant response of the organism through the activation of the nuclear related factor 2 (Nrf2) and consequently 
of some antioxidant responsive elements (AREs). Nrf2 is a basic leucine zipper transcription factor that upregulates ARE-driven detoxification and antioxidant genes. Since the expression of a wide array of antioxidant and detoxification genes is positively regulated by the ARE sequence, Nrf2 may serve as a master regulator of the ARE-driven cellular defense system against oxidative stress [46-50]. Since preliminary data of our group suggest that both strawberry fractions induce AMPK activity, this could be a possible mechanism of action; however, specific analyses are needed to confirm this hypothesis. In this sense, Yun et al. [49] demonstrated that AMPK activity plays an indispensable role in the operation of the ROS defense system by inducing the expression of the antioxidant enzymes (SOD and CAT) in response to resveratrol treatment in liver cells.

\section{Materials and Methods}

\subsection{Plant Material and Sampling Method}

Strawberry fruits Fragaria $\times$ Ananassa (cv. Romina) were collected in the experimental fields of the Agricultural Faculty of the Università Politecnica delle Marche, Italy. Fruit samples were hand-picked on the same day-time in different weeks, corresponding to the ripening times of this variety, and were selected for homogeneity, avoiding unripe, wounded or shriveled samples. Within $2 \mathrm{~h}$ after harvest, whole strawberries were stored at $-80^{\circ} \mathrm{C}$ until the analyses' execution.

\subsection{Methanolic Extract Preparation}

For methanolic extract preparation, $50 \mathrm{~g}$ of fruit were added to $100 \mathrm{~mL}$ of the extraction solution, consisting of methanol/Milli-Q water/concentrated formic acid (80:20:0.1, $v / v / v)$, and were homogenized using an Ultraturrax T25 homogenizer (Janke \& Kunkel, IKA Labortechnik, Staufen, Germany) at medium-high speed for $2 \mathrm{~min}$. Extraction was maximized by stirring the suspension at $22 \times g$ (ARE Magnetic stirrer, VELP Scientifica, Usmate, Italy) for $2 \mathrm{~h}$ in the dark at room temperature. The mixture was then centrifuged at $2400 \times g$ for 15 min for two sequential times, in order to sediment solids. Supernatants were filtered through a $0.45-\mu \mathrm{m}$ Minisart filter (PBI International, Milan, Italy) and transferred to a 5.0-mL amber glass. For subsequent experimental procedures, the methanolic extract was concentrated and dried through a rotary evaporator resulting in $1.6 \mathrm{~g}$ of dried material. The sample was stored in aliquots at $-80^{\circ} \mathrm{C}$.

\subsection{Extraction of the Anthocyanins Fraction}

The anthocyanin fraction was obtained as previously described by Alvarez-Suarez et al. [38]; $50 \mathrm{~g}$ of strawberries were homogenized in $100 \mathrm{~mL}$ of methanol containing $0.1 \% \mathrm{HCl}$, stirred overnight $\left(22 \times g, \sim 14 \mathrm{~h}, 3\right.$ to $\left.5{ }^{\circ} \mathrm{C}\right)$ and subsequently filtered through a Büchner funnel under vacuum. The solid residues were exhaustively washed with methanol, the number of times necessary to complete color extraction, and the filtrates obtained were centrifuged $\left(4000 \times \mathrm{g}, 15 \mathrm{~min}, 21^{\circ} \mathrm{C}\right)$. All supernatants were mixed, dried through a rotary evaporator and re-suspended in $50 \mathrm{~mL}$ of water. Subsequently, aliquots ( $2 \mathrm{~mL}$ ) of the aqueous phase were carefully charged into C18 SepPaks Vac 6cc cartridges (Waters, Milan, Italy) for solid phase extraction (SPE). Sugars and more polar substances were removed by passing $15 \mathrm{~mL}$ of ultrapure water, and anthocyanin pigments were further eluted with $5 \mathrm{~mL}$ of methanol $/ 0.1 \%$ trifluoroacetic acid $(95: 5, v / v)$. The final methanolic extract was concentrated and dried again through a rotary evaporator resulting in $0.73 \mathrm{~g}$ of dried material. The sample was stored in aliquots at $-80{ }^{\circ} \mathrm{C}$.

This kind of sample preparation permits removing sugar, organic acids and other water-soluble fruit constituents $[25,51]$ and to obtain a highly concentrated anthocyanin solution, mainly non-polymerized anthocyanins [51-53]. Usually, the C18 cartridges do not adsorb the phenolic acids, which are collected in the first eluent (water,) while catechins and flavonols are eluted together with the non-polymerized anthocyanins [54]. 


\subsection{Total Phenolic Content Determination}

TPC of the strawberry fractions was determined using the Folin-Ciocalteu method, as modified by Slinkard and Singleton [55]. Briefly, $100 \mu \mathrm{L}$ of water re-suspended strawberry fractions were added to $500 \mu \mathrm{L}$ of Folin-Ciocalteu solution and kept at $4{ }^{\circ} \mathrm{C}$ in the dark. Next, the mixture was incubated for 1 to $8 \mathrm{~min}$ at room temperature, and $400 \mu \mathrm{L}$ of $0.7 \mathrm{M}$ sodium carbonate $\left(\mathrm{Na}_{2} \mathrm{CO}_{3}\right)$ were added. The solution was incubated for $2 \mathrm{~h}$ at room temperature $\left(\sim 23^{\circ} \mathrm{C}\right)$ in the dark, and the absorbance was read at $760 \mathrm{~nm}$. Gallic acid solutions $(0.5$ to $3.0 \mathrm{mM})$ were used as the standard.

\subsection{Total Flavonoid Content Determination}

TFC was determined through a colorimetric method previously described by Jia et al. [56] and Dewanto et al. [57]. Briefly, $250 \mu \mathrm{L}$ of water re-suspended strawberry fractions were mixed with $1.25 \mathrm{~mL}$ of Milli-Q water, followed by the addition of $75 \mu \mathrm{L}$ of a $5 \%$ sodium nitrate $\left(\mathrm{NaNO}_{2}\right)$ solution. After $6 \mathrm{~min}, 150 \mu \mathrm{L}$ of a $10 \%$ aluminum chloride hexahydrate $\left(\mathrm{AlCl}_{3} \cdot 6 \mathrm{H}_{2} \mathrm{O}\right)$ solution were added to the mixture and allowed to stand for $5 \mathrm{~min}$. Then, $500 \mu \mathrm{L}$ of $1 \mathrm{M}$ sodium hydroxide $(\mathrm{NaOH})$ were added; the mixture was brought to $2.5 \mathrm{~mL}$ with Milli-Q water; and the absorbance was immediately read at $510 \mathrm{~nm}$. (+)-Catechin solutions $(0.0125$ to $0.1 \mathrm{mg} / \mathrm{mL})$ were used as the standard.

\subsection{Total Antioxidant Capacity Determination}

For determination of TAC of the strawberry fractions, three different methods were employed: the FRAP assay, the DPPH free radical method and the TEAC assay.

The FRAP assay was carried out according to the protocol proposed by Deighton et al. [58], with slight modifications from the original method [59]. The antioxidant capacity of samples is determined by their ability to reduce ferric to ferrous ion. When iron is complexed with 2,4,6-tripyridyl-s-triazine (TPTZ) in sodium acetate solution at an acidic $\mathrm{pH}$, its reduction results in a solution color change from pale rust to blue. The absorbance of the solution at $593 \mathrm{~nm}$ reflects the extent of the reduction.

The DPPH method was carried out according to the protocol proposed by Kumaran and Karunakaran [60]. It is based on the spectrophotometric measurement of the free radical DPPH reduction at $515 \mathrm{~nm}$.

The TEAC assay was carried out according to the method proposed by $\operatorname{Re}$ et al. [61]. This method is based on the ability of antioxidant compounds to quench the 2,2'-azinobis(3-ethylbenzothiazoline-6-sulfonic acid) (ABTS) radical with the consequent decrease in the absorbance values measured at $734 \mathrm{~nm}$.

\subsection{HPLC-MS Analysis}

HPLC analyses were carried out in a Hewlett-Packard 1100 chromatograph (Agilent Technologies, Waldbronn, Germany) equipped with a quaternary pump and a diode array detector (DAD) coupled to an HP Chem Station(Santa Clara, CA, USA) (rev. A.05.04) data-processing station. The HPLC system was connected via the DAD cell outlet to an API 3200 Qtrap (Applied Biosystems, Darmstadt, Germany) mass spectrometer (MS) consisting of an ESI source and a triple quadrupole-ion trap mass analyzer, which was controlled by the Analyst 5.1 software (Waltham, MA, USA).

\subsubsection{Analysis of Anthocyanins}

An AQUA ${ }^{\circledR}$ (Phenomenex, Madrid, Spain) reverse phase C18 column $(5 \mu \mathrm{m}, 150 \mathrm{~mm} \times 4.6 \mathrm{~mm})$ thermostated at $35{ }^{\circ} \mathrm{C}$ was used. The solvents were: (A) $0.1 \%$ trifluoroacetic acid and (B) acetonitrile. The elution gradient established was: isocratic 10\% B for $3 \mathrm{~min}, 10$ to $15 \%$ B in 12 min, isocratic $15 \%$ B for $5 \mathrm{~min}, 15$ to $18 \%$ B over $5 \mathrm{~min}, 18$ to $30 \%$ B over $20 \mathrm{~min}, 30$ to $35 \%$ B over $5 \mathrm{~min}$ and re-equilibration of the column to initial solvent conditions. The flow rate used was $0.5 \mathrm{~mL} / \mathrm{min}$. Double online detection was carried out in the DAD using 280 and $520 \mathrm{~nm}$ as preferred wavelengths and in the MS operated in the positive ion mode. Spectra were recorded between $\mathrm{m} / z 100$ and $\mathrm{m} / \mathrm{z} 1500$. Zero grade 
air served as the nebulizer gas (40 psi) and as turbo gas $\left(600^{\circ} \mathrm{C}\right)$ for solvent drying $(50 \mathrm{psi})$. Nitrogen served as the curtain (100 psi) and collision gas (high). Both quadrupoles were set at unit resolution, and the MS detector was programmed to perform a series of two consecutive analyses, a full scan of high sensitivity (enhanced MS (EMS)) and an enhanced product ion analysis (EPI) to obtain the fragmentation pattern of the parent ion. The EMS mode parameters were the following: ion spray voltage $5000 \mathrm{~V}$, declustering potential (DP) $41 \mathrm{~V}$, entrance potential (EP) $7.5 \mathrm{~V}$ and collision energy (CE) $10 \mathrm{~V}$. EPI mode was applied using the following settings: DP $41 \mathrm{~V}, \mathrm{EP} 7.5 \mathrm{~V}, \mathrm{CE} 10 \mathrm{~V}$ and collision energy spread (CES) $0 \mathrm{~V}$.

Compounds were identified by their retention time, UV-Vis spectra and mass spectra, as well as comparison with our data library and standards when available. The compounds were quantified from the areas of their chromatographic peaks recorded at $520 \mathrm{~nm}$ using pelargonidin-3-O-glucoside for calibration curves.

\subsubsection{Analysis of Flavonols and Other Phenolic Derivatives}

An AQUA ${ }^{\circledR}$ (Phenomenex) reverse phase C18 column $(5 \mu \mathrm{m}, 150 \mathrm{~mm} \times 4.6 \mathrm{~mm})$ thermostated at $35{ }^{\circ} \mathrm{C}$ was used. The solvents were: (A) $0.1 \%$ formic acid and (B) acetonitrile. The elution gradient established was isocratic $15 \%$ B for $5 \mathrm{~min}, 15$ to $20 \%$ B over $5 \mathrm{~min}, 20$ to $35 \%$ B over $10 \mathrm{~min}, 35$ to $50 \%$ B over $10 \mathrm{~min}, 50$ to $60 \%$ B over $5 \mathrm{~min}$, isocratic $60 \%$ B for $5 \mathrm{~min}$ and re-equilibration the column to initial solvent conditions. The flow rate was $0.5 \mathrm{~mL} / \mathrm{min}$. Double online detection was carried out in the DAD at 280, 330 and $370 \mathrm{~nm}$ as preferred wavelengths and in the MS operated in the negative ion mode. Spectra were recorded between $m / z 100$ and $m / z$ 1500. Zero grade air served as the nebulizer gas ( $30 \mathrm{psi})$ and as turbo gas $\left(400{ }^{\circ} \mathrm{C}\right)$ for solvent drying ( $\left.40 \mathrm{psi}\right)$. Nitrogen served as the curtain $(20 \mathrm{psi})$ and collision gas (medium). Both quadrupoles were set at unit resolution, and EMS and EPI analyses were also performed. The EMS parameters were: ion spray voltage $4500 \mathrm{~V}, \mathrm{DP}-50 \mathrm{~V}, \mathrm{EP}-6 \mathrm{~V}, \mathrm{CE}$ $-10 \mathrm{~V}$ and cell exit potential (CXP) $-3 \mathrm{~V}$; whereas EPI settings were: DP $-50 \mathrm{~V}, \mathrm{EP}-6 \mathrm{~V}, \mathrm{CE}-25 \mathrm{~V}$ and CES $0 \mathrm{~V}$.

Compounds were identified by their retention time, UV-Vis spectra and mass spectra, as well as the comparison with our data library and standards when available. The compounds were quantified from the areas of their chromatographic peaks recorded at 280 and $360 \mathrm{~nm}$ using ellagic acid, quercetin and kaempferol glucoside for the calibration curves constructed.

\subsection{Cells Culture and Cells' Lysates Preparation}

HepG2 cells were kindly provided by the Biological Research Laboratory of Seville University (Seville, Spain) and were grown in Dulbecco's Modified Eagle's Medium (DMEM), supplemented with $10 \%$ fetal bovine serum (FBS), $100 \mathrm{IU} / \mathrm{mL}$ penicillin and $100 \mu \mathrm{g} / \mathrm{mL}$ streptomycin until 80 to $90 \%$ of confluence when sub-cultured. Cells were maintained in a HeraCell $\mathrm{CO}_{2}$ incubator at $37^{\circ} \mathrm{C}$ with $5 \% \mathrm{CO}_{2}$. After treatments with the strawberry fractions for the indicated periods, cells were lysed in the RIPA buffer (Sigma-Aldrich, Milan, Italy) for lipid profile, lipid peroxidation and enzyme activity determination. All of the analyses were conducted on cells between the 3rd and the 6th passage.

\subsection{Cell Viability: MTT Assay}

For cell viability assessment, HepG2 cells were seeded into 96-well plates at a density of $5 \times 10^{3}$ cells/well and treated with different concentrations (from 0 to $1 \mathrm{mg} / \mathrm{mL}$ ) of the strawberry fractions for 24,48 and $72 \mathrm{~h}$. Both the dried methanolic extract and the anthocyanin fraction were directly dissolved in the cell culture medium. After incubation, $30 \mu \mathrm{L}$ of RPMI medium containing $2 \mathrm{mg} / \mathrm{mL}$ of MTT were added in each well, and cells were incubated for other $2 \mathrm{~h}$ at $37^{\circ} \mathrm{C}$. MTT solution was then discarded, and $100 \mu \mathrm{L}$ of DMSO were added into each well to dissolve the formazan crystal. The level of colored formazan derivative was analyzed on a microplate reader (Thermo Scientific Multiskan ${ }^{\circledR}$ EX, Monza, Italy) at a wavelength of $590 \mathrm{~nm}[62,63]$. The viable cells were directly proportional to the formazan production. 


\subsection{Determination of Triglycerides and LDL-Cholesterol Content}

LDL-cholesterol and triglyceride contents were determined by enzymatic colorimetric kits (Spinreact, St. Esteve d'en Bas, Girona, Spain) using a microplate reader (Thermo Scientific, Multiskan ${ }^{\circledR}$ EX, Monza, Italy) coupled to an Ascent software (Thermo LabSystems Oy, Version 2.6, Milan, Italy).

\subsection{Determination of Lipid Peroxidation: TBARs Assay}

Lipid peroxidation was measured by the TBAR assay according to a standardized method proposed by Ohkawa et al. [64]. Briefly, $300 \mu \mathrm{L}$ of cellular lysate were mixed with the thiobarbituric acid (TBA) reagent (TBA, $0.37 \%$ in $0.2 \mathrm{M} \mathrm{HCl}$ ) and $15 \%$ trichloroacetic acid (TCA) and heated at $95{ }^{\circ} \mathrm{C}$ for $20 \mathrm{~min}$. Then, the mixture was cooled, centrifuged at $1200 \times \mathrm{g}$ for $15 \mathrm{~min}$ at $4{ }^{\circ} \mathrm{C}$, and the supernatant absorbance was measured at $532 \mathrm{~nm}$.

\subsection{Assessment of Intracellular ROS Production by the Tali ${ }^{\circledR}$ Image-Based Cytometer}

Determination of intracellular ROS levels was performed using the CellROX ${ }^{\circledR}$ Oxidative Stress Kit (Invitrogen TM, Life Technologies, Milan, Italy) according to the manufacturer's instructions. Briefly, cells were seeded in 6-well plates at a density of $1.5 \times 10^{5}$ cells/well and treated with different concentrations of the strawberry fractions for $24 \mathrm{~h}$. The concentrations used for each fraction were chosen according to the MTT viability assay ensuring a vitality greater than $90 \%$. After treatment, cells were detached by trypsinization and centrifuged at $556 \times g$ for $10 \mathrm{~min}$ at $4{ }^{\circ} \mathrm{C}$. The supernatant was discarded, re-suspending the cellular pellet in $1 \mathrm{~mL}$ of complete medium. Then, CellROX ${ }^{\circledR}$ Orange Reagent was added at a final concentration of $5 \mu \mathrm{M}$, and samples were incubated for $30 \mathrm{~min}$ at $37^{\circ} \mathrm{C}$, centrifuged once to remove medium and dye excesses and re-suspended again in PBS. After labeling with CellROX ${ }^{\circledR}$ Orange Reagent, cells were analyzed with the Tali ${ }^{\circledR}$ Image-Based cytometer (Thermo Fisher Scientific, Milan, Italy).

\subsection{Evaluation of Antioxidant Enzymes Activity}

SOD activity was assayed according to the method proposed by Kakkar et al. [65]. The method is based on the dismutation of the superoxide radical to oxygen and $\mathrm{H}_{2} \mathrm{O}_{2}$. Briefly, the assay mixture contained $1.2 \mathrm{~mL}$ of $0.025 \mathrm{M}$ sodium pyrophosphate buffer, $\mathrm{pH} 8.3,100 \mu \mathrm{L}$ of $186 \mu \mathrm{M}$ phenazine methosulfate, $300 \mu \mathrm{L}$ of $300 \mu \mathrm{M}$ nitroblue tetrazolium, $190 \mu \mathrm{L} \mathrm{mL}$ of PBS, $10 \mu \mathrm{L}$ of the cellular lysate and $1 \mathrm{~mL}$ of water, for a total volume of $2.8 \mathrm{~mL}$. The reaction was initiated by the addition of $10 \mu \mathrm{L}$ of $\mathrm{NADH}$, and the mixture was incubated at $30^{\circ} \mathrm{C}$ for $90 \mathrm{~s}$ and arrested by the addition of $1.0 \mathrm{~mL}$ of glacial acetic acid. The reaction mixture was then shaken with $2 \mathrm{~mL}$ of n-butanol, allowed to stand for $10 \mathrm{~min}$ and centrifuged at $1300 \times \mathrm{g}$ for another $10 \mathrm{~min}$. The intensity of the chromogen in the butanol layer was measured at $540 \mathrm{~nm}$ in a microplate reader (Thermo Scientific, Multiskan ${ }^{\circledR}$ EX, Monza, Italy).

CAT activity was assayed according to the method proposed by Aebi [66]. The method is based on the decomposition of $\mathrm{H}_{2} \mathrm{O}_{2}$ by the action of the enzyme. Briefly, the assay mixture consisted of $990 \mu \mathrm{L}$ of sodium phosphate buffer $(50 \mathrm{mM}) \mathrm{pH}$ 7, $500 \mu \mathrm{L}$ of $\mathrm{H}_{2} \mathrm{O}_{2}(30 \%)$ and $10 \mu \mathrm{L}$ of the cellular lysate. The decrease in absorbance due to $\mathrm{H}_{2} \mathrm{O}_{2}$ degradation was monitored at $240 \mathrm{~nm}$ past 10 to $70 \mathrm{~s}$ of reaction.

\section{Conclusions}

Our results demonstrated that strawberry fractions not only improved the lipid metabolism by decreasing triglycerides and LDL-cholesterol contents, but also improved the redox state of HepG2 cells by modulating TBARs production, antioxidant enzyme activity and ROS generation. The anthocyanin-enriched fraction resulted in being more effective than the whole methanolic extract for almost all of the evaluated parameters. Further studies must be conducted in order to confirm these findings also in humans or animal models. 
Acknowledgments: The authors wish to thank Monica Glebocki for extensively editing the manuscript.

Author Contributions: Tamara Y. Forbes-Hernández, Massimiliano Gasparrini and Francesca Giampieri conceived and designed the experiments under the supervision of Maurizio Battino and Stefano Bompadre. Tamara Y. Forbes-Hernández, Sadia Afrin and Danila Cianciosi performed cell cultures experiments while Ana M. González-Paramás performed the HPLC analyses. Bruno Mezzetti provided strawberry fruit and contributed reagents/materials/analysis tools together with Maurizio Battino, José L. Quiles and Celestino Santos-Buelga. Tamara Y. Forbes-Hernández and Francesca Giampieri wrote the paper. All of the authors made essential contributions to the manuscript revision and approved the final version of the text.

Conflicts of Interest: The authors declare no conflicts of interest.

\section{References}

1. Van Duyn, M.A.; Pivonka, E. Overview of the health benefits of fruit and vegetable consumption for the dietetics professional: Selected literature. J. Am. Diet. Assoc. 2000, 100, 1511-1521. [CrossRef]

2. Slavin, J.L.; Lloyd, B. Health Benefits of Fruits and Vegetables. Adv. Nutr. 2012, 3, 506-516. [CrossRef] [PubMed]

3. Klimis-Zacas, D.; Vendrame, S.; Kristo, A.S. Wild blueberries attenuate risk factors of the metabolic syndrome. J. Berry Res. 2016, 6, 225-236. [CrossRef]

4. Esmaillzadeh, A.; Kimiagar, M.; Mehrabi, Y.; Azadbakht, L.; Hu, F.; Willett, W. Fruit and vegetable intakes, C-reactive protein, and the metabolic syndrome. Am. J. Clin. Nutr. 2006, 84, 1489-1497. [PubMed]

5. Cheraghi, Z.; Mirmiran, P.; Mansournia, M.A.; Moslehi, N.; Khalili, D.; Nedjat, S. The association between nutritional exposures and metabolic syndrome in the Tehran Lipid and Glucose Study (TLGS): A cohort study. Public Health 2016, 140, 163-171. [CrossRef] [PubMed]

6. Luo, T.; Miranda-Garcia, O.; Adamson, A.; Sasaki, G.; Shay, N.F. Development of obesity is reduced in high-fat fed mice fed whole raspberries, raspberry juice concentrate, and a combination of the raspberry phytochemicals ellagic acid and raspberry ketone. J. Berry Res. 2016, 6, 213-223. [CrossRef]

7. Edirisinghe, I.; Burton-Freeman, B. Anti-diabetic actions of Berry polyphenols-Review on proposed mechanisms of action. J. Berry Res. 2016, 6, 237-250. [CrossRef]

8. Edirisinghe, I.; Banaszewski, K.; Cappozzo, J.; Sandhya, K.; Ellis, C.L.; Tadapaneni, R.; Kappagoda, C.T.; Burton-Freeman, B.M. Strawberry anthocyanin and its association with postprandial inflammation and insulin. Br. J. Nutr. 2011, 106, 913-922. [CrossRef] [PubMed]

9. McCullough, M.L.; Peterson, J.J.; Patel, R.; Jacques, P.F.; Shah, R.; Dwyer, J.T. Flavonoid intake and cardiovascular disease mortality in a prospective cohort of US adults. Am. J. Clin. Nutr. 2012, 95, 454-464. [CrossRef] [PubMed]

10. Bazzano, L.A.; Serdula, M.K.; Liu, S. Dietary intake of fruits and vegetables and risk of cardiovascular disease. Curr. Atheroscler. Rep. 2003, 5, 492-499. [CrossRef] [PubMed]

11. Wagner, K.H.; Brath, H. A global view on the development of non-communicable diseases. Prev. Med. 2012, 54, 38-41. [CrossRef] [PubMed]

12. World Health Organization. Global Status Report on Non-Communicable Diseases 2014; WHO Press: Geneva, Switzerland, 2015; ISBN 978-92-4-156485-4.

13. Alvarez-Suarez, J.M.; Giampieri, F.; Tulipani, S.; Casoli, T.; Di Stefano, G.; González-Paramás, A.M.; Santos-Buelga, C.; Busco, F.; Quiles, J.L.; Cordero, M.D.; et al. One-month strawberry-rich anthocyanin supplementation ameliorates cardiovascular risk, oxidative stress markers and platelet activation in humans. J. Nutr. Biochem. 2014, 25, 289-294. [CrossRef] [PubMed]

14. Cassidy, A.; Mukamal, K.J.; Liu, L.; Franz, M.; Eliassen, A.H.; Rimm, E.B. A high anthocyanin intake is associated with a reduced risk of myocardial infarction in young and middle-aged women. Circulation 2013, 127, 188-196. [CrossRef] [PubMed]

15. Rangel-Huerta, O.D.; Pastor-Villaescusa, B.; Aguilera, C.M.; Gil, A. A Systematic Review of the Efficacy of Bioactive Compounds in Cardiovascular Disease: Phenolic Compounds. Nutrients 2015, 7, 5177-5216. [CrossRef] [PubMed]

16. Goldberg, A.C. Overview of Lipid Metabolism, Merck Manuals Professional Edition. 2015. Available online: http://www.merckmanuals.com/professional/endocrine-and-metabolic-disorders/lipiddisorders/overview-of-lipid-metabolism (accessed on 18 January 2016).

17. Houston, M.C. New concepts in cardiovascular disease. J. Restor. Med. 2013, 2, 30-44. [CrossRef] 
18. León-Fernández, O.; Martínez-Sánchez, G. Balance Redox y las Enfermedades. In Balance Antioxidante-Prooxidante: Salud y Enfermedad; Martínez-Sánchez, G., Ed.; Palco: La Habana, Cuba, 2005.

19. Capocasa, F.; Scalzo, J.; Mezzetti, B.; Battino, M. Combining quality and antioxidant attributes in the strawberry: The role of genotype. Food Chem. 2008, 111, 872-878. [CrossRef]

20. Tulipani, S.; Mezzetti, B.; Capocasa, F.; Bompadre, S.; Beekwilder, J.; de Vos, C.H.; Capanoglu, E.; Bovy, A.; Battino, M. Antioxidants, phenolic compounds, and nutritional quality of different strawberry genotypes. J. Agric. Food Chem. 2008, 56, 696-704. [CrossRef] [PubMed]

21. Mazzoni, L.; Perez-Lopez, P.; Giampieri, F.; Alvarez-Suarez, J.M.; Gasparrini, M.; Forbes-Hernandez, T.Y.; Quiles, J.L.; Mezzetti, B.; Battino, M. The genetic aspects of berries: From field to health. J. Sci. Food Agric. 2016, 30, 365-371. [CrossRef] [PubMed]

22. Giampieri, F.; Alvarez-Suarez, J.M.; Battino, M. Strawberry and human health: Effects beyond antioxidant activity. J. Agric. Food Chem. 2014, 62, 3867-3876. [CrossRef] [PubMed]

23. Tulipani, S.; Marzban, G.; Herndl, A.; Laimer, M.; Mezzetti, B.; Battino, M. Influence of environmental and genetic factors on health-related compounds in strawberry. Food Chem. 2011, 124, 906-913. [CrossRef]

24. Capocasa, F.; Balduccia, F.; Di Vittori, L.; Mazzoni, M.; Stewart, D.; Williams, S.; Hargreaves, R.; Bernardini, D.; Danesi, L.; Zhong, C.F.; et al. Romina and Cristina: Two New Strawberry Cultivars with High Sensorial and Nutritional Values. Int. J. Fruit Sci. 2016, 16, 207-219. [CrossRef]

25. Dai, J.; Mumper, R.J. Plant Phenolics: Extraction, Analysis and Their Antioxidant and Anticancer Properties. Molecules 2010, 15, 7313-7352. [CrossRef] [PubMed]

26. He, J.; Giusti, M. High-purity isolation of anthocyanins mixtures from fruits and vegetables-A novel solid-phase extraction method using mixed mode cation-exchange chromatography. J. Chromatogr. A 2011, 1218, 7914-7922. [CrossRef] [PubMed]

27. Da Silva Pinto, M.; Lajolo, F.M.; Genovese, M.I. Bioactive compounds and quantification of total ellagic acid in strawberries (Fragaria $x$ ananassa Duch.). Food Chem. 2008, 107, 1629-1635. [CrossRef]

28. Aaby, K.; Mazur, S.; Nes, A.; Skrede, G. Phenolic compounds in strawberry (Fragaria x ananassa Duch.) fruits: Composition in 27 cultivars and changes during ripening. Food Chem. 2012, 132, 86-97. [CrossRef] [PubMed]

29. Sandhu, A.K.; Huang, Y.; Xiao, D.; Park, E.; Edirisinghe, I.; Burton-Freeman, B. Pharmacokinetic Characterization and Bioavailability of Strawberry Anthocyanins Relative to Meal Intake. J. Agric. Food Chem. 2016, 64, 4891-4899. [CrossRef] [PubMed]

30. Prior, R.L.; Wu, X.; Gu, L.; Hager, T.; Hager, A.; Wilkes, S.; Howard, L. Purified berry anthocyanins but not whole berries normalize lipid parameters in mice fed an obesogenic high fat diet. Mol. Nutr. Food Res. 2009, 53, 1406-1418. [CrossRef] [PubMed]

31. Fotschki, B.; Juśkiewicz, J.; Jurgoński, A.; Kołodziejczyk, K.; Milala, J.; Kosmala, M.; Zduńczyk, Z. Anthocyanins in Strawberry Polyphenolic Extract Enhance the Beneficial Effects of Diets with Fructooligosaccharides in the Rat Cecal Environment. PLoS ONE 2016, 11, e0149081. [CrossRef] [PubMed]

32. Qin, Y.; Xia, M.; Ma, J.; Hao, Y.T.; Liu, Y.; Mou, H.Y.; Cao, L.; Ling, W.H. Anthocyanin supplementation improves serum LDL- and HDL-cholesterol concentrations associated with the inhibition of cholesteryl ester transfer protein in dyslipidemic subjects. Am. J. Clin. Nutr. 2009, 90, 485-492. [CrossRef] [PubMed]

33. Curtis, P.J.; Kroon, P.A.; Hollands, W.J.; Walls, R.; Jenkins, G.; Kay, C.D.; Cassidy, A. Cardiovascular Disease Risk Biomarkers and Liver and Kidney Function Are Not Altered in Postmenopausal Women after Ingesting an Elderberry Extract Rich in Anthocyanins for 12 Weeks. J. Nutr. 2009, 139, 2266-2271. [CrossRef] [PubMed]

34. Lee, S.G.; Vance, T.M.; Nam, T.G.; Kim, D.O.; Koo, S.I. Contribution of anthocyanins composition to total antioxidant capacity of berries. Plant Foods Hum. Nutr. 2015, 70, 427-432. [CrossRef] [PubMed]

35. Manach, C.; Williamson, G.; Morand, C.; Scalbert, A.; Rémésy, C. Bioavailability and bioefficacy of polyphenols in humans. I. Review of 97 bioavailability studies. Am. J. Clin. Nutr. 2005, 81 (Suppl. 1), 230S-242S. [PubMed]

36. Banaszewski, K.; Park, E.; Edirisinghe, I.; Cappozzo, J.C.; Burton-Freeman, B.M. A pilot study to investigate bioavailability of strawberry anthocyanins and characterize postprandial plasma polyphenols absorption patterns by Q-TOF LC/MS in humans. J. Berry Res. 2013, 3, 113-126. [CrossRef]

37. Giampieri, F.; Tulipani, S.; Alvarez-Suarez, J.M.; Quiles, J.L.; Mezzetti, B.; Battino, M. The strawberry: Composition, nutritional quality, and impact on human health. Nutrition 2012, 28, 9-19. [CrossRef] [PubMed] 
38. Alvarez-Suarez, J.M.; Dekanski, D.; Ristić, S.; Radonjić, N.V.; Petronijević, N.D.; Giampieri, F.; Astolfi, P.; González-Paramás, A.M.; Santos-Buelga, C.; Tulipani, S.; et al. Strawberry polyphenols attenuate ethanol induced gastric lesions in rats by activation of antioxidant enzymes and attenuation of MDA increase. PLoS ONE 2011, 6, e25878. [CrossRef] [PubMed]

39. Repetto, M.; Semprine, J.; Boveris, A. Lipid Peroxidation: Chemical Mechanism, Biological Implications and Analytical Determination. In Biochemistry, Genetics and Molecular Biology; Catala, A., Ed.; InTech Open Science: Rijeka, Croatia, 29 August 2012; ISBN 978-953-51-0716-3.

40. Giampieri, F.; Alvarez-Suarez, J.M.; Mazzoni, L.; Forbes-Hernandez, T.Y.; Gasparrini, M.; Gonzalez Paramas, A.M.; Santos-Buelga, C.; Quiles, J.L.; Bompadre, S.; Mezzetti, B.; et al. An anthocyanin-rich strawberry extract protects against oxidative stress damage and improves mitochondrial functionality in human dermal fibroblasts exposed to an oxidizing agent. Food Funct. 2014, 5, 1939-1948. [CrossRef] [PubMed]

41. Giampieri, F.; Alvarez-Suarez, J.M.; Mazzoni, L.; Forbes-Hernandez, T.Y.; Gasparrini, M.; Gonzalez Paramas, A.M.; Santos-Buelga, C.; Quiles, J.L.; Bompadre, S.; Mezzetti, B.; et al. Polyphenol-Rich Strawberry Extract Protects Human Dermal Fibroblasts against Hydrogen Peroxide Oxidative Damage and Improves Mitochondrial Functionality. Molecules 2014, 19, 7798-7816. [CrossRef] [PubMed]

42. Galambos, A.R. The Effects of Blueberry Anthocyanidins on Antioxidant Enzyme Activity in Human Hepg2 Cells. Thesis Submitted to the Graduate Faculty of The University of Georgia in Partial Fulfillment of the Requirements of the Degree Master of Science Athens, Georgia, 2012.

43. Zhao, J.; Hui, D.; Luo, M.; Wang, W.; Zhao, C.J.; Zu, Y.G.; Fu, Y.J.; Wink, M. In vitro antioxidant activities and antioxidant enzyme activities in HepG2 cells and main active compounds of endophytic fungus from pigeon pea (Cajanus cajan (L.) Millsp.). Food Res. Int. 2014, 56, 243-251. [CrossRef]

44. Martin, M.A.; Ramos, S.; Mateos, R.; Granado-Serrano, A.B.; Izquierdo-Pulido, M.; Bravo, L.; Goya, L. Protection of Human HepG2 Cells against Oxidative Stress by Cocoa Phenolic Extract. J. Agric. Food Chem. 2008, 56, 7765-7772. [CrossRef] [PubMed]

45. Khan, M.A.; Chen, H.C.; Wan, X.X.; Tania, M.; Xu, A.H.; Chen, F.Z.; Zhang, D.Z. Regulatory effects of resveratrol on antioxidant enzymes: A mechanism of growth inhibition and apoptosis induction in cancer cells. Mol. Cells 2013, 35, 219-225. [CrossRef] [PubMed]

46. Jeong, H.W.; Hsu, K.C.; Lee, J.W.; Ham, M.; Huh, J.Y.; Shin, H.J.; Kim, W.S.; Kim, J.B. Berberine suppresses proinflammatory responses through AMPK activation in macrophages. Am. J. Physiol. Endocrinol. Metab. 2009, 296, E955-E964. [CrossRef] [PubMed]

47. Hwang, Y.P.; Choi, J.H.; Yun, H.J.; Han, E.H.; Kim, H.G.; Kim, J.Y.; Park, B.H.; Khanal, T.; Choi, J.M.; Chung, Y.C.; et al. Anthocyanins from purple sweet potato attenuate dimethylnitrosamine-induced liver injury in rats by inducing Nrf2-mediated antioxidant enzymes and reducing COX-2 and iNOS expression. Food Chem. Toxicol. 2011, 49, 93-99. [CrossRef] [PubMed]

48. Sid, B.; Verrax, J.; Calderon, P.B. Role of AMPK activation in oxidative cell damage: Implications for alcohol-induced liver disease. Biochem. Pharmacol. 2013, 86, 200-209. [CrossRef] [PubMed]

49. Yun, H.; Park, S.; Kim, M.J.; Yang, W.K.; UkIm, D.; Yang, K.R.; Hong, J.; Choe, W.; Kang, I.; Kim, S.S.; et al. AMP-activated protein kinase mediates the antioxidant effects of resveratrol through regulation of the transcription factor FoxO1. FEBS J. 2014, 281, 4421-4438. [CrossRef] [PubMed]

50. Li, Z.; Jiang, J.D.; Kong, W.J. Berberine Up-Regulates Hepatic Low-Density Lipoprotein Receptor through Ras-Independent but AMP-Activated protein kinase-dependent Raf-1 Activation. Biol. Pharm. Bull. 2014, 37, 1766-1775. [CrossRef] [PubMed]

51. Kraemer-Schafhalter, A.; Fuchs, H.; Pfannhauser, W. Solid-Phase Extraction Comparison (SPE)—A Comparisonof 16 Materials for the Purification of Anthocyanins from Aronia melanocarpa var Nero. J. Sci. Food Agric. 1998, 78, 435-440. [CrossRef]

52. Welch, C.R.; Wu, Q.; Simon, J.E. Recent Advances in Anthocyanin Analysis and Characterization. Curr. Anal. Chem. 2008, 4, 75-101. [CrossRef] [PubMed]

53. Ferreiro-González, M.; Carrera, C.; Ruiz-Rodríguez, A.; Barbero, G.F.; Ayuso, J.; Palma, M.; Barroso, C.G. A New Solid Phase Extraction for the Determination of Anthocyanins in Grapes. Molecules 2014, 19, 21398-21410. [CrossRef] [PubMed]

54. Pinelo, M.; Laurie, F.; Waterhouse, A. A Simple Method to Separate Red Wine Nonpolymeric and Polymeric Phenols by Solid-Phase Extraction. J. Agric. Food Chem. 2006, 54, 2839-2844. [CrossRef] [PubMed] 
55. Slinkard, K.; Singleton, V.L. Total Phenol analysis: Automation and comparison with manual methods. Am. J. Enol. Vitic. 1977, 28, 49-55.

56. Jia, Z.; Tang, M.; Wu, J. The determination of flavonoid contents in mulberry and their scavenging effects on superoxides radicals. Food Chem. 1998, 64, 555-559.

57. Dewanto, V.; Wu, X.; Adom, K.K.; Liu, R.H. Thermal processing enhances the nutritional values of tomatoes by increasing the total antioxidant activity. J. Agric. Food Chem. 2002, 50, 3010-3014. [CrossRef] [PubMed]

58. Deighton, N.; Brennan, R.; Finn, C.; Davies, H.V. Antioxidant properties of domesticated and wild Rubus species. J. Sci. Food Agric. 2000, 80, 1307-1313. [CrossRef]

59. Benzie, I.F.; Strain, J.J. Ferric reducing ability of plasma (FRAP) as a measure of antioxidant power: The FRAP assay. Anal. Biochem. 1996, 239, 70-76. [CrossRef] [PubMed]

60. Kumaran, A.; Karunakaran, R.J. Activity-guided isolation and identification of free radical scavenging components from an aqueous extract of Coleus aromaticus. Food Chem. 2007, 100, 356-361. [CrossRef]

61. Re, R.; Pellegrini, N.; Proteggente, A.; Pannala, A.; Yang, M.; Rice-Evans, C.A. Antioxidant activity applying an improved ABTS radical cation decolorization assay. Free Radic. Biol. Med. 1999, 26, 1231-1237. [CrossRef]

62. Moongkarndi, P.; Srivattana, A.; Bunyapraphatsara, N.; Puthong, S.; Laohathai, K. Cytotoxicity assay of hispidulin and quercetin using colorimetric technique. Mahidol Univ. J. Pharm. Sci. 1991, 18, $25-31$.

63. Studzinski, G.P. Cell Growth and Apoptosis a Practical Approach; Oxford University Press: Oxford, UK, 1995; ISBN 978-01-9-963569-6.

64. Ohkawa, H.; Ohishi, N.; Yagi, K. Assay for lipid peroxides in animal tissues by thiobarbituric acid reaction. Anal. Biochem. 1979, 95, 351-358. [CrossRef]

65. Kakkar, P.; Das, B.; Viswanathan, P.N. A modified spectrophotometric assay of superoxide dismutase. Indian J. Biochem. Biophys. 1984, 21, 130-132. [PubMed]

66. Aebi, H. Catalase in vitro. Methods Enzymol. 1984, 105, 121-126. [PubMed]

(C) 2017 by the authors. Licensee MDPI, Basel, Switzerland. This article is an open access article distributed under the terms and conditions of the Creative Commons Attribution (CC BY) license (http://creativecommons.org/licenses/by/4.0/). 